\title{
Cooperation in the supply chain of fisheries: A case study of the north central region, Vietnam
}

\author{
Phuong Tran Hoa ${ }^{a^{*}}$, Dung Nguyen Anh ${ }^{\mathrm{b}}$ and Ha Nguyen Thi Thu ${ }^{\mathrm{c}}$
}

a Institute of Political economics, Ho Chi Minh National Academy of Politics, Vietnam

${ }^{b} V N U$ University of Economics \& Business, Vietnam

${ }^{c}$ Hanoi University National Resources and Environment, Vietnam

\section{H R O N I C L E}

\begin{tabular}{l}
\hline Article history: \\
Received January 27, 2021 \\
Received in revised format \\
January, 28, 2021 \\
Accepted May 202021 \\
Available online \\
May 202021 \\
\hline Keywords: \\
Cooperation \\
Supply Chain Collaboration \\
Fisheries Supply Chain \\
Supply Chain Management
\end{tabular}

\section{A B S T R A C T}

\section{Introduction}

The importance of supply chain management is more focused when organizations recognize the benefits of cooperation (Power, 2005). As the economy is growing, specialization is increasing, organizations will tend to increase cooperation with other members in the supply chain to use the quality resources of their partners at a lower cost than self-manufacturing but inefficient (Abiola, 2008). As a result, organizations increasingly want to get closer to each other to effectively manage supply and distribution channels to both optimize costs and increase customer satisfaction, contributing to improving product competitiveness and improve the profitability of participating organizations (Simatupang et al., 2002). Therefore, many researchers agree that: competition is taking place between supply chains and supply chains, not between businesses and enterprises (Manuj et al., 2008). Many researchers have tried to find and identify the prerequisites for organizations participating in supply chain cooperation (Albino, 2008; Ding, 2011; Zhu, 2010). Supply chain cooperation is due to global competitive pressures or risks due to environmental fluctuations including changes in supply, demand and technology, opportunities from new markets (Tate, 2010; Chen 2017). However, according to experts in the seafood industry, in addition to global competitive pressure, other environmental pressures also have a great impact on the level of cooperation between members in the supply chain such as risks related to supply chains such as supply, markets, information, and the environment (Garcia, 2010). In addition, the business strategy of the business is one of the most important factors determining the degree of cooperation with member partners in the supply chain (Ellram, 1990). The North Central Region is the low-lying sector of the country's economy (VCCI, 2020). This area has $15 \%$ of the country's population but just 5.5 percent of the country's companies. The upper and lower layers of the North Central Region are home to a variety of marine migratory fish, the majority of which are shrimp, crabs, crabs, clams, squid, and... People in the North Central Region exploit and produce with increasing catches. According to General Department of Fisheries statistics, the entire region has the potential to develop nearly 163900 ha of aquaculture areas, with nearly 115,600 ha for freshwater farming and over 48,300 ha for salty and brackish water farming and tens of millions of hectares of unexploited reservoir water surface with 194 reservoirs. According to the Directorate of Fisheries (2020), the quality of economic growth in the fisheries sector in this area is primarily based on growth factors in width, rather than quantity; as a result, efficiency is low. Growth in average fishing output in the period 2010-2014 is still primarily determined by an increase in the number of fishing boats, with productivity

* Corresponding author

E-mail address: thphuong6888@gmail.com (P. T. Hoa)

C 2021 by the authors; licensee Growing Science. doi: $10.5267 /$ j.uscm.2021.5.008 
growth accounting for less than $10 \%$. Growth in output value is primarily determined by an increase in production, with price increases accounting for a low proportion of $15 \%$. Currently, there are quite a few studies on the relationship between supply chain collaboration and business performance (Ratajczak-Mrozek, 2012; Wadhwa, 2010). However, the studies did not show consistent results. Therefore, it is necessary to clearly define the factors influencing supply chain cooperation and further test in other contexts. Therefore, the study will clarify the supply chain cooperation through the study and better identification of the influencing factors both internal and external.

\section{Literature review and Hypothesis}

\subsection{Supply chain collaboration}

In supply chain management, supply chain collaboration is defined as two or more autonomous firms working jointly to plan and execute supply chain operations. It can deliver substantial benefits and advantages to its partners (Cao et al., 2011). Due to the asymmetry between supply and demand, there are always contradictions in supply chains (Gan, 2010). This is explained by the fact that each supply chain consists of independent organizations involved in the flows of goods, services, and related information as well as financial flows from the point of origin to the final customer. Organizational members are often involved in supply chain management to effectively plan, implement, and control flows to meet customer needs (Lambert,2000). Conflicts in the chain stem from members' distrust of each other, difficulties in relationships that occur before and during cooperation (Simatupang, 2002). Besides, the cause of conflict is also due to the difference in attitudes and structure and the source of power, coercive or non-coercive, also affects the disagreement among the members of the chain (Zhao et al., 2008). Through the results of published studies, it is possible to draw out several factors that researchers have discovered and tested separately, including trust, distance, strategies, policies, power, and maturity.

\subsection{Hypothesis}

Trust reflects a trust in a partner and involves some aspect of weakness and uncertainty in the trusted partner (Smith, 1997). A successful relationship is characterized by mutual trust, and businesses that trust each other are consistently profitable, serve customers better, and are more adaptable (Sin et al., 2002). Tangible assets can play an important role in fostering trust among the partners of intermediaries (Clark, 1999). While later studies suggested that trust is a function of civic relations behavior and frequent interactions. Both above studies emphasize the trust between organizations to minimize the cost of administrative procedures (Lui, 2004).

\section{$\mathbf{H}_{1}$ : Trust has an impact on supply chain collaboration.}

Distance between partners in a supply chain means to refer to the geographical, cultural, and organizational distances between the partners in that supply chain (van Donk, 2010). Distance in general has a certain effect on cooperation in the supply chain. That is, the closer the distance between partners, the closer the partners have similarities in culture, language, and business practices. So that makes it easier for partners to choose each other and cooperate with each other.

\section{$\mathbf{H}_{2}$ : Distance has an impact on supply chain collaboration.}

When researching the supply chain of cooperation, the cooperation strategy includes 4 basic contents, which are: the strategy of mergers and acquisitions, the strategy of capital rationalization, the strategy of optimizing the combinations on production, and the new product introduction strategy (Anderson, 2004). Cooperation strategies in the series include basic activities such as planning, forecasting and supplementing the content of cooperation in the supply chain (Stadtler, 2005).

\section{H3: Strategies have an impact on supply chain collaboration.}

Any business that wants to participate in the supply chain in the industry but does not meet national and international policies and laws will find it difficult to cooperate (Tate, 2010). In the complex and extensive operation of the supply chain, there is a need to improve cooperation between businesses and the Government, nationally and internationally, to control and manage risks in the global supply chain.

\section{H4: Policies have an impact on supply chain collaboration.}

Power is seen as central to all business relationships (Hingley, 2005). The power of a business or organization over a partner is determined by the extent to which the business or organization depends on specific resources on another (Inkpen et al 1997). In a relationship, when one party with more power is more likely to pressure the less powerful party to make decisions in favor of the more powerful party (Kumar, 1996). In the supply chain there is not a strong relationship between power and dependence. In the relationship between the buyer and the seller, the more unilateral power, the higher the use of a contract with clear and detailed terms.

\section{Hs: Power has an impact on supply chain collaboration.}

Increasing supply chain interaction as much as possible leads to less uncertainty in supply and demand forecasts and improved business performance (Wilding, 1998). This is the best way to pursue and gain competitive advantage. The characteristics of relationship maturation are: predictability, competence, control power, effectiveness, and efficiency (De Treville et al., 2004). 


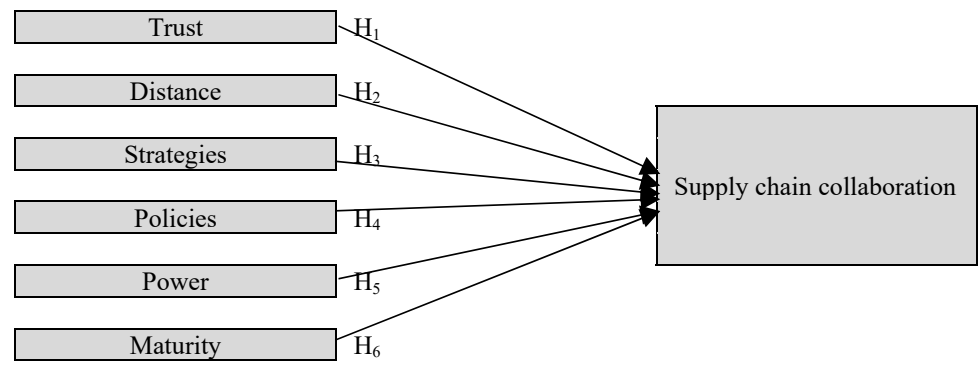

\section{Methodology}

Fig. 1. Theoretical framework

\subsection{Sample and Data Collection}

Not only in the North Central Region, but also in Vietnam, the fishing industry has a lot of room for development. Since the study focused on the impact of supply chain cooperation on transport performance in the fisheries sector, those interviewed were those who caught, farmed, and traded aquatic products such as shrimp, fish, different types of cockles, and so on. The survey collected 300 questionnaires in six provinces in the North Central Region: Thanh Hoa (55 samples), Nghe An (45 samples), Ha Tinh (50 samples), Quang Binh (45 samples), Quang Tri (55 samples), and Thua Thien - Hue (50 samples)

\subsection{Method of Analysis}

Application validation can be done by testing the measurement model as an external model and checking for reflection value and reliability. The convergence value with a factor loading of more than 0.6 and the average vaiance extracted (AVE) of more than 0.5 (Chin, 1995) can be used to determine how well the value is obtained. Then, if Cronbach's alpha and composite reliability (CR) are both greater than 0.7, a structure meets the reliability criterion (Hair, et al., 2014). This research then used Structural Equation Model (SEM) analysis with SmartPLS 3.0 software to evaluate the data and test hypotheses.

\section{Results}

\subsection{Measurement Model}

Table 1 presents details of som loading factors, t-vlue, mean and VIF for all components of the survey.

Table 1

Descriptive statistics, reliability, and validity

\begin{tabular}{|c|c|c|c|c|c|}
\hline Code & Items & Factor's loading & t-value & Mean & VIF \\
\hline \multicolumn{6}{|c|}{ Trust (Cronbach's alpha: 0.868, CR: 0.919, AVE: 0.791) } \\
\hline T1 & Improve the common good & 0.875 & 63.671 & 3.47 & 2.221 \\
\hline $\mathrm{T} 2$ & Effectively balance supply and demand & 0.899 & 78.790 & 3.46 & 2.400 \\
\hline T3 & Trust partners & 0.895 & 77.142 & 3.45 & 2.227 \\
\hline \multicolumn{6}{|c|}{ Distance (Cronbach's alpha: 0.632, CR: 0.844, AVE: 0.730) } \\
\hline D1 & Cultural & 0.824 & 21.643 & 3.37 & 1.272 \\
\hline D2 & Geography & 0.883 & 35.844 & 3.34 & 1.272 \\
\hline \multicolumn{6}{|c|}{ Strategies (Cronbach's alpha: 0.820, CR: 0.893, AVE: 0.735) } \\
\hline S1 & Merger and acquisition strategy & 0.841 & 34.398 & 2.82 & 1.753 \\
\hline $\mathrm{S} 2$ & Capital rationalization strategy & 0.858 & 37.747 & 2.64 & 1.789 \\
\hline $\mathrm{S} 3$ & New product introduction strategy & 0.873 & 44.295 & 2.78 & 2.036 \\
\hline \multicolumn{6}{|c|}{ Policies (Cronbach's alpha: 0.773, CR: 0.868, AVE: 0.687) } \\
\hline P1 & Non-tariff barriers & 0.804 & 24,600 & 3.75 & 1.526 \\
\hline $\mathrm{P} 2$ & Traceability of origin & 0.837 & 33.201 & 3.37 & 1.604 \\
\hline P3 & Economic development environment & 0.845 & 32.333 & 3.49 & 1.638 \\
\hline \multicolumn{6}{|c|}{ Power (Cronbach's alpha: 0.768, CR: 0.865, AVE: 0.682) } \\
\hline Po1 & Oppress & 0.811 & 17.268 & 2.88 & 1.520 \\
\hline Po2 & Support & 0.858 & 25.596 & 2.97 & 1.605 \\
\hline Po3 & Interactive & 0.807 & 16.073 & 2.72 & 1.585 \\
\hline \multicolumn{6}{|c|}{ Maturity (Cronbach's alpha: 0.779, CR: 0.870, AVE: 0.691) } \\
\hline M1 & Demand forecast & 0.795 & 21.828 & 3.37 & 1.569 \\
\hline M2 & Increase competitive advantage & 0.818 & 29.091 & 3.31 & 1.588 \\
\hline M3 & Improve business efficiency & 0.879 & 16.073 & 3.41 & 1.695 \\
\hline \multicolumn{6}{|c|}{ Supply chain collaboration (Cronbach's alpha: 0.827, CR: 0.885, AVE: 0.659) } \\
\hline $\mathrm{SCC} 1$ & Improve labor productivity & 0.806 & 32.735 & 3.23 & 1.737 \\
\hline $\mathrm{SCC} 2$ & Increase market share & 0.824 & 42.930 & 3.12 & 1.875 \\
\hline $\mathrm{SCC} 3$ & Increase profits & 0.800 & 34.703 & 3.16 & 1.701 \\
\hline $\mathrm{SCC} 4$ & Improve labor productivity & 0.817 & 39.502 & 3.06 & 1.822 \\
\hline
\end{tabular}




\subsection{Hypothesis Test Results}

Table 2 and Fig. 2 present details of testing the hypotheses of the survey.

Table 2

Hypothesis Test

\begin{tabular}{lccc} 
& Hypothesis Test & P_value & Results \\
\hline H1 & Trust has an impact on supply chain collaboration & 0.000 & Supported \\
H2 & Distance has an impact on supply chain collaboration & 0.039 & Supported \\
H3 & Strategies has an impact on supply chain collaboration & 0.000 & Supported \\
H4 & Policies has an impact on supply chain collaboration & 0.008 & Supported \\
H5 & Power has an impact on supply chain collaboration & 0.004 & Supported \\
H6 & Maturity has an impact on supply chain collaboration & 0.000 & Supported \\
\hline
\end{tabular}

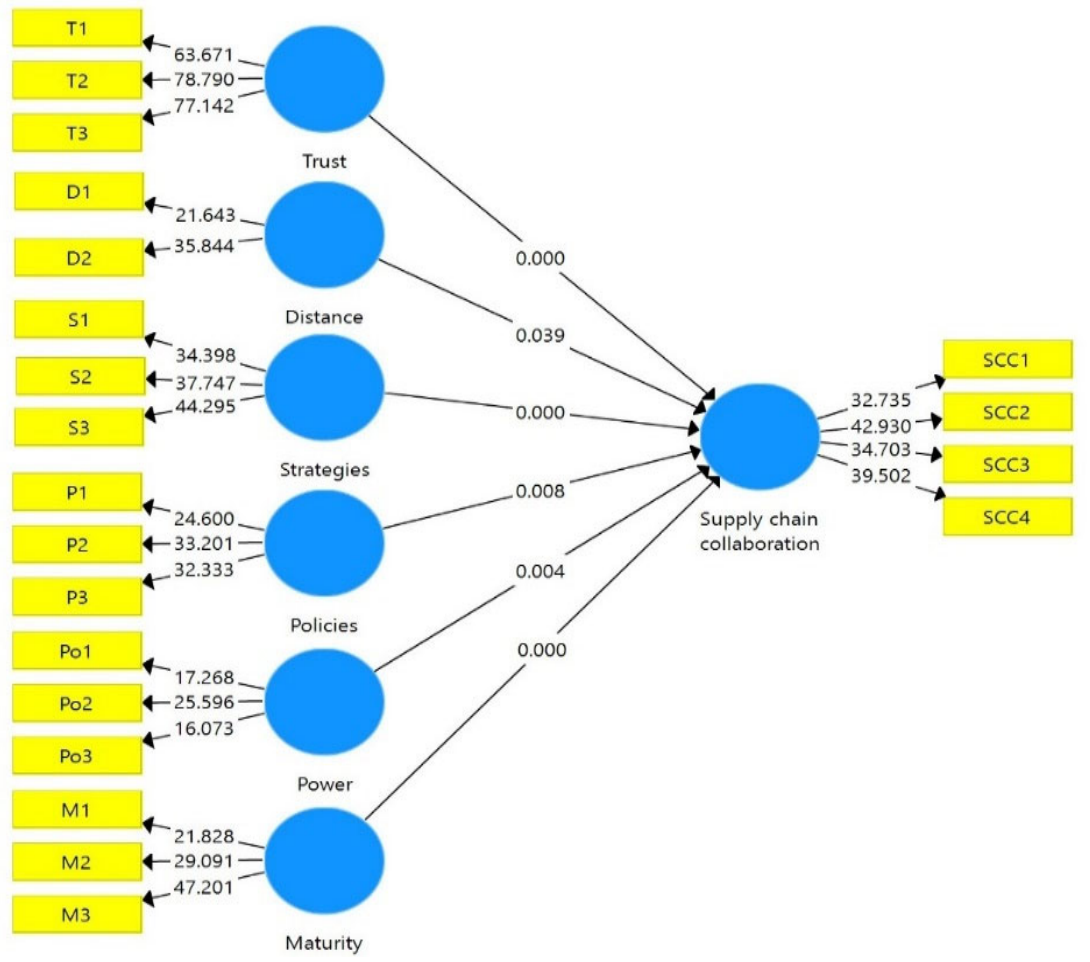

Fig. 2. The results of the path model

According to the results, all hypotheses of the survey have been confirmed.

\section{Conclusion}

Enterprises must pay attention to building corporate image to enhance the level of trust in transactions with partners. It includes brands, financial capabilities, payment methods, payment methods, shipping methods, shared information, and the ability to flexibly respond to changing needs. In particular, affirming the brand value in the development of Vietnam's seafood processing industry by promoting the application of technology in business, improving production techniques, and constantly focusing on improving the quality source of raw materials for processing.

Through research, power here implies the size, influence of enterprises in the industry and outside the industry, the position of enterprises, and current ownership in which economic sector? If the enterprise always focuses on developing the above aspects, the capacity of the enterprise is highly appreciated, and through that, the enterprise is eligible to strengthen and increase its power. Over the partner to achieve the target attract cooperation voluntarily as well as put pressure on partners to actively cooperate with enterprises in the chain.

Research shows that in addition to the main actors in the seafood supply chain, including suppliers, manufacturers, and distributors. For the supply chain of the industry to be effective, it is necessary to connect with relevant government agencies and industry associations. The reason is that the Government's policies have a certain influence on encouraging or discouraging enterprises to cooperate with each other to increase competitiveness and facilitate development in a proactive and sustainable manner. 


\section{References}

Abiola, B. O. (2008). The Nnewi automotive components cluster in Nigeria. Knowledge, Technology and Cluster-based Growth, 53.

Albino, V., Carbonara, N., \& Giannoccaro, I. (2007). Supply chain cooperation in industrial districts: A simulation analysis. European Journal of Operational Research, 177(1), 261-280.

Anderson, D. M. (2004). Build-to-Order \& Mass Customization: the ultimate supply chain management and lean manufacturing strategy for low-cost on-demand production without forecasts or inventory. CIM press.

Cao, M., \& Zhang, Q. (2011). Supply chain collaboration: Impact on collaborative advantage and firm performance. Journal of Operations Management, 29(3), 163-180.

Chen, L., Zhao, X., Tang, O., Price, L., Zhang, S., \& Zhu, W. (2017). Supply chain collaboration for sustainability: A literature review and future research agenda. International Journal of Production Economics, 194, 73-87.

Clark, T. H., \& Lee, H. G. (1999, January). Electronic intermediaries: Trust building and market differentiation. In Proceedings of the 32nd Annual Hawaii International Conference on Systems Sciences. 1999. HICSS-32. Abstracts and CD-ROM of Full Papers (pp. 10-pp). IEEE.

De Treville, S., Shapiro, R. D., \& Hameri, A. P. (2004). From supply chain to demand chain: the role of lead time reduction in improving demand chain performance. Journal of Operations Management, 21(6), 613-627.

Ding, H., Guo, B., \& Liu, Z. (2011). Information sharing and profit allotment based on supply chain cooperation. International Journal of Production Economics, 133(1), 70-79.

Ellram, L. M., \& Cooper, M. C. (1990). Supply chain management, partnership, and the shipper-third party relationship. The International Journal of Logistics Management, 1(2), 1-10.

Gan, X., Sethi, S. P., \& Zhou, J. (2010). Commitment-penalty contracts in drop-shipping supply chains with asymmetric demand information. European Journal of Operational Research, 204(3), 449-462.

Garcia, S. M., \& Rosenberg, A. A. (2010). Food security and marine capture fisheries: characteristics, trends, drivers and future perspectives. Philosophical Transactions of the Royal Society B: Biological Sciences, 365(1554), $2869-2880$.

Hingley, M. K. (2005). Power imbalanced relationships: cases from UK fresh food supply. International Journal of Retail \& Distribution Management, 33(8).

Inkpen, A. C., \& Beamish, P. W. (1997). Knowledge, bargaining power, and the instability of international joint ventures. Academy of Management Review, 22(1), 177-202.

Kumar, N. (1996). The power of trust in manufacturer-retailer relationships. Harvard Business Review, 74(6), 92.

Lambert, D. M., \& Cooper, M. C. (2000). Issues in supply chain management. Industrial Marketing Management, 29(1), 65-83.

Lui, S. S., \& Ngo, H. Y. (2004). The role of trust and contractual safeguards on cooperation in non-equity alliances. Journal of Management, 30(4), 471-485.

Manuj, I., \& Mentzer, J. T. (2008). Global supply chain risk management strategies. International Journal of Physical Distribution \& Logistics Management, 38(3).

Power, D. (2005). Supply chain management integration and implementation: a literature review. Supply Chain Management: An International Journal, 10(4).

Tate, W. L., Ellram, L. M., \& Kirchoff, J. F. (2010). Corporate social responsibility reports: a thematic analysis related to supply chain management. Journal of Supply Chain Management, 46(1), 19-44.

van Donk, D. P., van der Vaart, T., Awaysheh, A., \& Klassen, R. D. (2010). The impact of supply chain structure on the use of supplier socially responsible practices. International Journal of Operations \& Production Management, 30(12).

Ratajczak-Mrozek, M., \& Małys, Ł. (2012). Supply chain cooperation and company performance. Argumenta Oeconomica, $2(29), 89-107$.

Simatupang, T. M., \& Sridharan, R. (2002). The collaborative supply chain. The International Journal of Logistics Management, 13(1), 15-30.

Sin, L. Y., Alan, C. B., Yau, O. H., Lee, J. S., \& Chow, R. (2002). The effect of relationship marketing orientation on business performance in a service-oriented economy. Journal of Services Marketing, 16(7).

Smith, J. B., \& Barclay, D. W. (1997). The effects of organizational differences and trust on the effectiveness of selling partner relationships. Journal of Marketing, 61(1), 3-21.

Stadtler, H. (2005). Supply chain management and advanced planning — basics, overview and challenges. European Journal of Operational Research, 163(3), 575-588.

Wadhwa, S., Mishra, M., Chan, F. T., \& Ducq, Y. (2010). Effects of information transparency and cooperation on supply chain performance: a simulation study. International Journal of Production Research, 48(1), 145-166.

Wilding, R. (1998). The supply chain complexity triangle: uncertainty generation in the supply chain. International Journal of Physical Distribution \& Logistics Management, 28(8).

Zhao, X., Huo, B., Flynn, B. B., \& Yeung, J. H. Y. (2008). The impact of power and relationship commitment on the integration between manufacturers and customers in a supply chain. Journal of Operations Management, 26(3), 368388.

Zhu, Q., Geng, Y., \& Lai, K. H. (2010). Circular economy practices among Chinese manufacturers varying in environmental-oriented supply chain cooperation and the performance implications. Journal of Environmental Management, 91(6), 1324-1331 
(C) 2021 by the authors; licensee Growing Science, Canada. This is an open access article distributed under the terms and conditions of the Creative Commons Attribution (CC-BY) license (http://creativecommons.org/licenses/by/4.0/). 